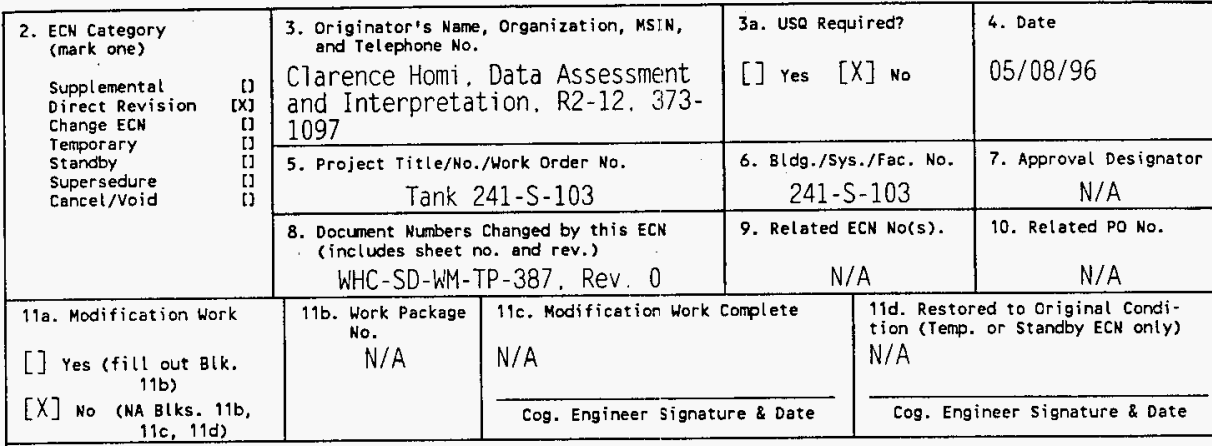

12. Description of Change

Complete revision.

13a. Justification (mark one)

$\begin{array}{llllllll}\text { Criteria Change } & {[X]} & \text { Design Improvenent } & {[]} & \text { Environnental } & \text { [] } & \text { Facility Deactivation [] } \\ \text { As-Found } & {[]} & \text { Facilitate Const } & {[]} & \text { Const. Error/Omission } & \text { [] } & \text { Design Error/Omission [] }\end{array}$

13b. Justification Details

Changed to comply with new template and DOE-RL recomended modifications.

14. Distribution (include name, MSIN, and no. of copies)

See attached distribution. 


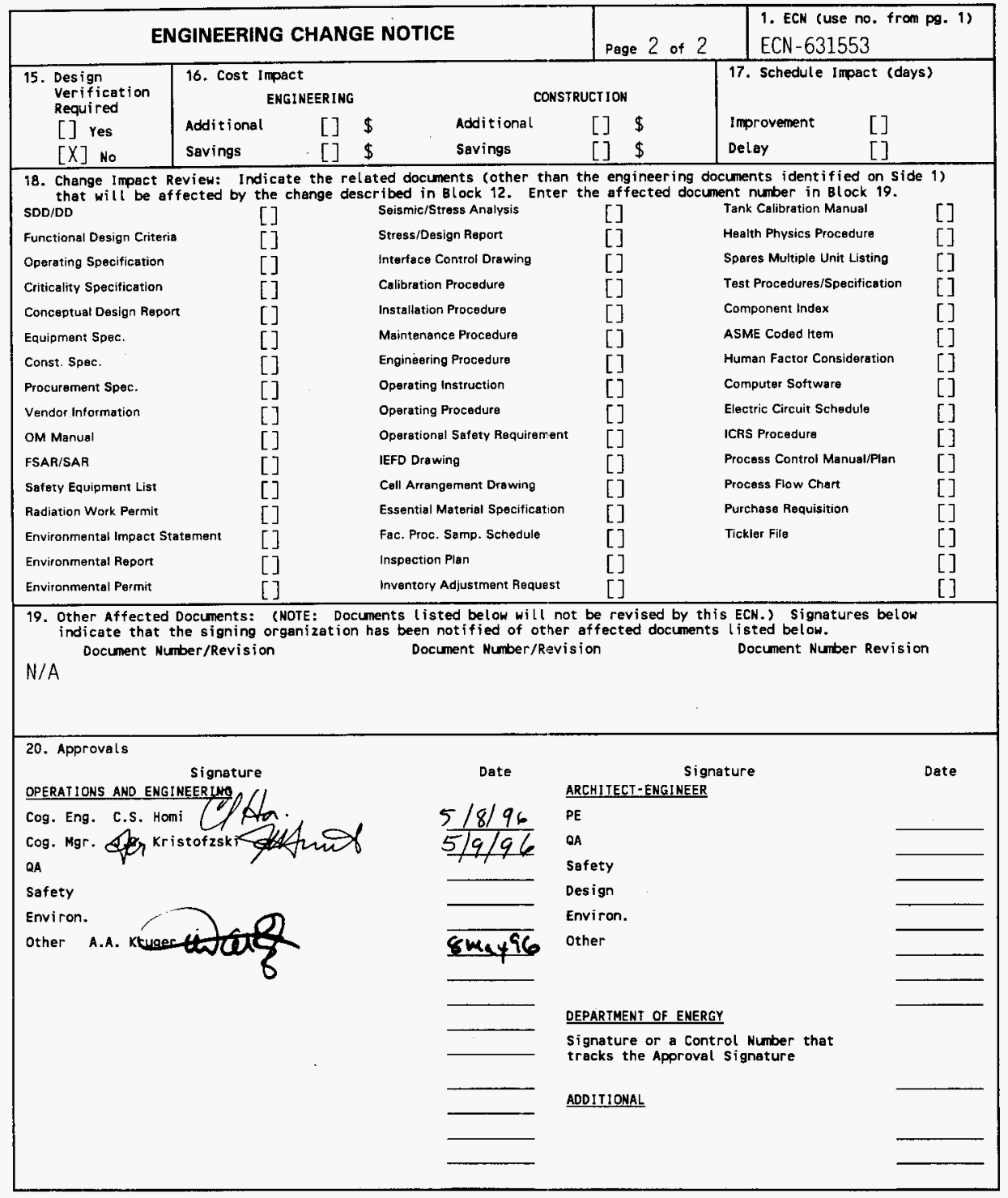




\title{
Tank 241-S-103 Tank Characterization Plan
}

\author{
C. S. Homi
}

Westinghouse Hanford Company, Richland, WA 99352

U.S. Department of Energy Contract DE-AC06-87RL10930

$\begin{array}{lll}\text { EDT/ECN: } & \text { ECN-631553 } & \text { UC: } 2070 \\ \text { Org Code: } & 79200 & \text { Charge Code: N4G6A } \\ \text { B\&R Code: } & \text { EW } 3120074 & \text { Total Pages: } 8\end{array}$

Key Words: Characterization. General Safety Issues. Specific Safety Issues, Information Requirements. Schedule

Abstract: This document is a plan that identifies the information needed to address relevant issues concerning short-term and long-term storage and long-term management of single-shell tank 241-5-103.

TRADEMARK DISCLAIMER. Reference herein to any specific commercial product, process, or service by trade name, trademark, manufacturer, or otherwise, does not necessarily constitute or imoly its endorsement, recommendation, or favoring by the United States Government or any agency thereof or its contractors or subcontractors.

Printed in the United States of America. To obtain copies of this document contact: HHC/BCS Document Control Services, P.O. Box 1970, Mailstop H6-08, Richland WA 99352, Phone (509) 372-2420; Fax (509) 376-4989.
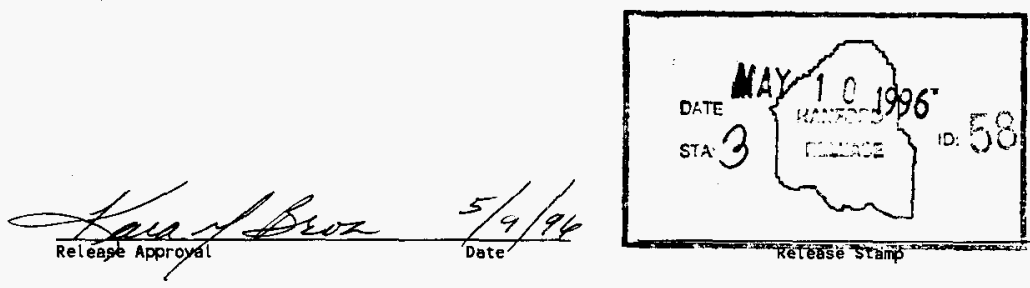

\section{Approved for Public Release}




\section{RECORD OF REVISION}

(2) Title

Tank 241-S-103 Tank Characterization Plan

CHANGE CONTROL RECORD

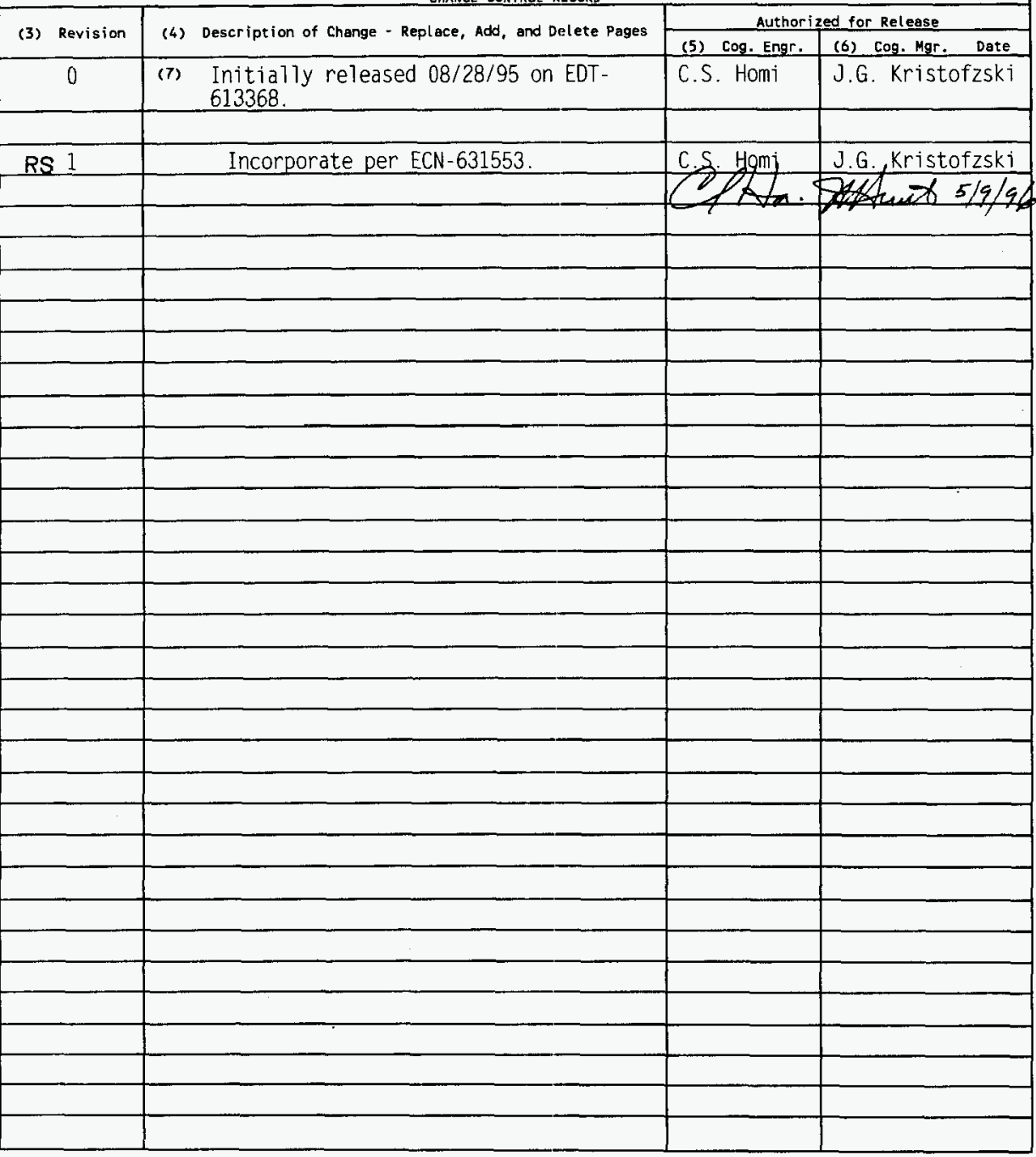


WHC-SD-WM-TP-387

Revision 1

UC-2070

\title{
Tank 241-S-103 \\ Tank Characterization Plan
}

\author{
A. A. Kruger \\ Westinghouse Hanford Company \\ Date Published \\ May 1996
}

Prepared for the U.S. Department of Energy

Office of Environmental Restoration and

Waste Management

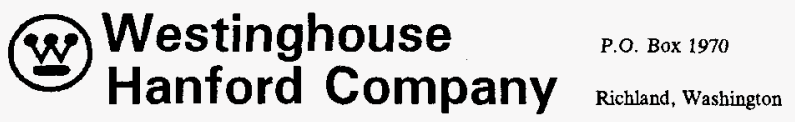

Management and Operations Contractor for the

U.S. Department of Energy under Contract DE-AC06-87RL10930

Approved for Public Release 
WHC-SD-WM-TP-387, REV 1

TABLE OF CONTENTS

1.0 INTRODUCTION 1

2.0 PROGRAM ELEMENTS REQUIRING INFORMATION FOR TANK 241-S-103 1

2.1 GENERAL SAFETY ISSUES 2

2.2 SPECIFIC SAFETY ISSUES

2.2.1 Ferrocyanide 2

2.2.2 Organic 2

2.2.3 High Heat 2

2.2.4 Flammable Gas 2

2.2 .5 Vapor 2

2.2.6 Criticality 2

2.3 CONTINUING OPERATIONS 3

2.3.1 Compatibility/Stabilization 3

2.3.2 Evaporator 3

2.4 DOUBLE-SHELL TANK WASTE ANALYSIS PLAN 3

2.5 DISPOSAL 3

2.5.1 Retrieval 3

2.5.2 Pretreatment/Vitrification 3

2.6 HISTORICAL MODEL EVALUATION 3

3.0 HOW INFORMATION WILL BE OBTAINED 3

4.0 PRIORITY OF INFORMATION REQUIREMENTS 4

5.0 WHEN INFORMATION WILL BE AVAILABLE 4

6.0 REFERENCES 4

LIST OF TABLES

Table 4-1: Integrated DQO Requirements and Priorities 


\section{WHC-SD-WM-TP-387, REV 1}

\subsection{INTRODUCTION}

This Tank Characterization Plan (TCP) identifies the information needed to address relevant issues concerning short-term and long-term safe storage, and long-term management of single-shel1 tank 241-S-103 (S-103). It should be understood that the various needs and issues surrounding tank S-103 are evolving as new information about the tank is uncovered. As a result of this progression, this TCP addresses only the issues that, to this date, have been identified. It is expected that deviations from this plan may occur as additional issues or needs arise which impact the management of tank S-103. As necessary, this TCP will be revised as necessary to reflect those changes or deviations. This plan reflects the best information available as of May 1996.

Tank S-103 was constructed between 1950 and 1951 and was put into service in November 1953. Tank S-103 is the third tank in a cascade flow series consisting, also, of tanks 241-S-102 and 241-S-102 (Brevick 1995). Tank S-103 started receiving waste from the Reduction 0xidation (REDOX) facility from the fourth quarter of 1953 until the fourth quarter of 1973. REDOX waste was the high-level component of the process waste. From the fourth quarter of 1973 until the second quarter of 1976, the tank received bottoms and recycle streams from the 242-5 Evaporator / Crystallizer. In the fourth quarter of 1976, the tank became a low-heat evaporator dump tank containing evaporator feed waste. Between the second quarter of 1978 and the fourth quarter of 1980, the tank was classified as having non-complexed, partial neutralized feed and double-shell slurry feed wastes. From the first quarter of 1978 until the fourth quarter of 1980 , the tank received a $\mathrm{HNO}_{3} / \mathrm{KMnO}_{4}$ solution (Brevick 1995). Tank S-103 was removed from service in 1980 and was partially isolated in December 1982 . Tank S-103 is ventilated passively.

Tank S-103 currently contains a total waste volume of $939 \mathrm{~kL}$ (248 kgals) which is equivalent to $250 \mathrm{~cm}$ (97 in) of waste as measured from the baseline of the tank (Hanion 1996).

This tank is not on any Watch List.

Near-term sampling and analysis activities are focused on either verifying or changing the Watch List tank status, and identifying any new safety issues. Should any safety issues be identified, additional analysis wijl occur consistent with the identified issue.

In addition to the resolution of the safety issues, it is intended that all tank waste will be subject to pretreatment and retrieval to prepare for final storage or disposal. Presently, these long-range plans have yet to be fully identified and are, therefore, not included in this document.

\subsection{PROGRAM ELEMENTS REQUIRING INFORMATION FOR TANK 241-S-103}

This section identifies the various program elements, and identifies which of these programs require characterization data from tank S-103. 


\subsection{GENERAL SAFETY ISSUES}

The Tank Safety Screening Data Quality Objective (Dukelow et al. 1995) describes the sampling and analytical requirements that are used to screen waste tanks for unidentified safety issues. Analytical requirements for the safety screening of a tank are energetics, total alpha activity, moisture content, density, and flammable gas concentration.

\subsection{SPECIFIC SAFETY ISSUES}

\subsubsection{Ferrocyanide}

This tank is not on the Ferrocyanide watch List; therefore, no information needs are currently identified for this program element.

\subsubsection{Organic}

This tank is not on the Organics watch List; therefore, no information needs are currently identified for this program element.

\subsubsection{High Heat}

This tank is not on the High Heat Watch List; therefore, no information needs are currently identified for this program element.

\subsubsection{Flammable Gas}

This tank is not on the Flammable Gas Watch List; therefore, no information needs are currently identified for this program element.

\subsubsection{Vapor}

Al1 177 underground tanks must be vapor-sampled for organic solvent screening as per Recommendation 93-5 Implementation Plan (DOE-RL 1996). Some tanks may require additional vapor sampling due to other program needs. These tanks may be classified into four categories: (1) those tanks which are to be rotary mode core sampled (as a consequence of the rotary sampling system exhauster permit requirements); (2) tanks on the Organic or Ferrocyanide Watch Lists; (3) tanks in C farm; and (4) tank 241-BX-104, due to vapor exposure. Information needs must satisfy Data Quality objectives for Tank Hazardous Vapor Safety Screening (Osborne and Buckley 1995), and for rotary mode on $1 y$, Rotary Core Vapor Sampling Data Quality Objective (Price 1994), and Data Quality Objective for Regulatory Requirements for Hazardous and Radioactive Air Emissions Sampling and Analysis (Mulkey and Markillie 1995) as amended by Status of the Current Understanding of the Toxic Air Pollutants (TAPS) and Hanford Tank Farm Vapor Space Characterization; Recommended Path Forward and Justification for Continued RMCS Exhauster Operations (Laws 1996). Tank C-104 was vapor sampled in March 1994 in support of Osborne et al. (1994).

\subsubsection{Criticality}

No information separate from that for the general safety issue of tank S-103 are currently identified for this program element. However, if the general safety screening of tank S-103 identifies a potential criticality concern, analyses for 


\section{WHC-SD-WM-TP-387, REV 1}

fissile materials and neutron absorbers and poisons will be performed as identified in the safety screening data quality objective (DQO).

\subsection{CONTINUING OPERATIONS}

\subsubsection{Compatibility/Stabilization}

This section does not apply to tank S-103.

\subsubsection{Evaporator}

This section does not apply to tank S-103.

\subsection{DOUBLE-SHELL TANK WASTE ANALYSIS PLAN}

This section does not apply because tank $\$-103$ is a single shell tank.

\subsection{DISPOSAL}

\subsubsection{Retrieval}

Current retrieval needs (Bloom and Nguyen 1995) do not call for test samples to be taken from tank S-103.

\subsubsection{Pretreatment/Vitrification}

Tank S-103 has been identified as a bounding tank for pretreatment/disposal process development Strategy (Kupfer et al. 1995). The strategy only requires that sample material be made available via archive samples and does not require any specific analyses to be done on the samples.

\subsection{HISTORICAL MODEL EVALUATION}

Bounding tanks and data requirements for historical model evaluations are found in Historical Model Evaluation Data Requirements (Simpson and McCain 1995). Tank S103 has been identified as a primary bounding tank for saltcake waste types and horizontal spatial variability. All single-shell tanks were prioritized in the Tank Waste Characterization Basis, (Brown et al. 1995) document using the historical DQO.

\subsection{HOW INFORMATION WILL BE OBTAINED}

The number of samples required to characterize a tank is a function of waste heterogeneity and the desired confidence to make a correct decision. As directed by the safety screening DQO, if inadequate information exists to determine an appropriate number of samples, two vertical profiles will be obtained. These vertical profiles may be obtained using core, auger (for shallow tanks), or grab samples. If analysis of these profiles reveals that additional profiles are required to meet data needs, more sample profiles will be requested. Prior to rotary sampling it is necessary to vapor sample the tank as per requirements of Rotary Core Vapor Sampling Data Quality Objective (Price 1994). 
WHC-SD-WM-TP-387, REV 1

\subsection{PRIORITY OF INFORMATION REQUIREMENTS}

Vapor sampling is scheduled for May 1996. Rotary mode core sampling is scheduled to begin in June 1996 (Stanton 1996). Refer to Table 4-1 for the current DQO requirements and $\mathrm{planned}$ sampling and analytical requirements.

Table 4-1: Integrated DQO Requirements and Priorities

\begin{tabular}{||l|l|l|l||}
\hline $\begin{array}{l}\text { Sampling } \\
\text { Event }\end{array}$ & \multicolumn{1}{|c|}{ Applicable Issues } & Sampling Requirements & \multicolumn{1}{c|}{$\begin{array}{c}\text { Analytical } \\
\text { Requirements }\end{array}$} \\
\hline $\begin{array}{l}\text { Vapor } \\
\text { Sampling }\end{array}$ & $\begin{array}{l}\text {-Organic Solvent Layer } \\
93-5 \text { Vapor Issue } \\
\text {-Rotary Mode Sampling } \\
\text { DQ0 } \\
\text {-Hazardous Vapor DQ0 }\end{array}$ & $\begin{array}{l}\text { Steel canisters, } \\
\text { Triple Sorbent Traps, } \\
\text { Sorbent Trap Systems }\end{array}$ & $\begin{array}{l}\text { Flammable Gas } \\
\text { Organic Vapors } \\
\text { Permanent Gases }\end{array}$ \\
\hline $\begin{array}{l}\text { Rotary } \\
\text { Sode Core } \\
\text { Sampling }\end{array}$ & $\begin{array}{l}\text {-Safety Screening DQO } \\
\text {-Historical DQO }\end{array}$ & $\begin{array}{l}\text { Core samples from a } \\
\text { minimum of 2 risers } \\
\text { separated radially to } \\
\text { the maximum extent } \\
\text { possible } \\
\text { Combustible gas } \\
\text { measurement }\end{array}$ & $\begin{array}{l}\text { Flammability, } \\
\text { Energetics, Moisture, } \\
\text { Density, Anions, } \\
\text { Metals, Radionuclides, } \\
\text { Total Organic Carbon }\end{array}$ \\
\hline
\end{tabular}

* Consult each applicable DQO in force at the time for sampling and analytical requirements.

\subsection{WHEN INFORMATION WILL BE AVAILABLE}

According to Stanton (1996) data are expected to be available from the rotary mode core sampling event for tank S-103 in October 1996. Vapor data are expected in July 1996. These times may be altered if the sampling schedule changes.

\subsection{REFERENCES}

Bloom, G. R. and Q. H. Nguyen, 1995, Characterization Data Needs for Development, Design, and Operation of Retrieval Equipment Developed Through the Data Quality Objective Process, WHC-SD-WM-DQ0-008, Rev. 0, Westinghouse Hanford Company, Richland, Washington.

Brevick, C. H., 1995, Historical Tank Content Estimate for the Southwest Quadrant of the Hanford 200 West Area, WHC-SD-WM-ER-352, Rev. OA, Westinghouse Hanford Company, Richland, Washington.

Brown, T. M., S. J. Eberlein, and T. J. Kunthara, 1995, Tank Waste Characterization Basis, 1995, WHC-SD-WM-TA-164, Rev 1, Westinghouse Hanford Company, Richland, Washington. 


\section{WHC-SD-WM-TP-387, REV 1}

DOE-RL, 1996, Recommendation 93-5 Implementation P7an, DOE/RL-94-0001, Rev. 1, U.S. Department of Energy, Richland, Washington.

Dukelow, G. T., J. W. Hunt, H. Babad, and J. E. Meacham, 1995, Tank Safety Screening Data Quality objective, WHC-SD-WM-SP-004, Rev 2, Westinghouse Hanford Company, Richland, Washington.

Hanlon, B.M., 1996, Waste Tank Summary for Month Ending January 31, 1996, WHC-EP-0182-94, Westinghouse Hanford Company, Richland, Washington.

Kupfer, M. J., W. W. Schultz, J. T. Slankas, 1995, Strategy for Sampling Hanford Site Tank Wastes for Development of Disposal Technology, WHC-SD-WM-TA-154, Rev. 1 , Westinghouse Hanford Company, Richland, Washington.

Laws, G. L., 1996, Status of the Current Understanding of the Toxic Air Pollutants (TAPS) and Hanford Tank Farm Vapor Space Characterization; Recommended Path Forward and Justification for Continued RMCS Exhauster Operations, (telephone conference memorandum, 01830-96-022, to Distribution, March 8) Westinghouse Hanford Company, Richland, Washington

Mulkey, C. H. K. D. Markillie, 1995, Data Quality Objective for Regulatory Requirements for Hazardous And Radioactive Air Emissions Sampling and Analysis, WHC-SD-WM-DQO-021, Rev. 0, Westinghouse Hanford Company, Richland, Washington

Osborne, J. W., L. L. Buckley, 1995, Data Quality Objectives for Tank Hazardous Vapor Safety Screening, WHC-SD-WM-DQ0-002, Rev. 2, Westinghouse Hanford, Richland, Washington.

Osborne, J. W., J. L. Huckaby, E. R. Hewitt, C. M. Anderson, D. D. Mahlum, B. A. Pulsipher, and J. Y. Young, 1994, Data Quality Objectives for Generic In-Tank Health and Safety Vapor Issue Resolution, WHC-SD-WM-DQ0-002, Rev. 0, Westinghouse Hanford, Richland, Washington.

Price, D. N. 1994, Rotary Core Vapor Sampling Data Quality Objective, WHC-SD-WM-SP-003, Rev. 0, Westinghouse Hanford Company, Richland, Washington.

Simpson, B. C., D. J. McCain, 1995, Historical Model Evaluation Data Requirements, WHC-SD-WM-DQ0-018, Rev. 0, Westinghouse Hanford Company, Richland, Washington.

Stanton, G. A., 1995, Baseline Sampling Schedule, Change 96-02, (internal memo 75610-96-06, to Distribution, April 17), Westinghouse Hanford Company, Richland, Washington. 


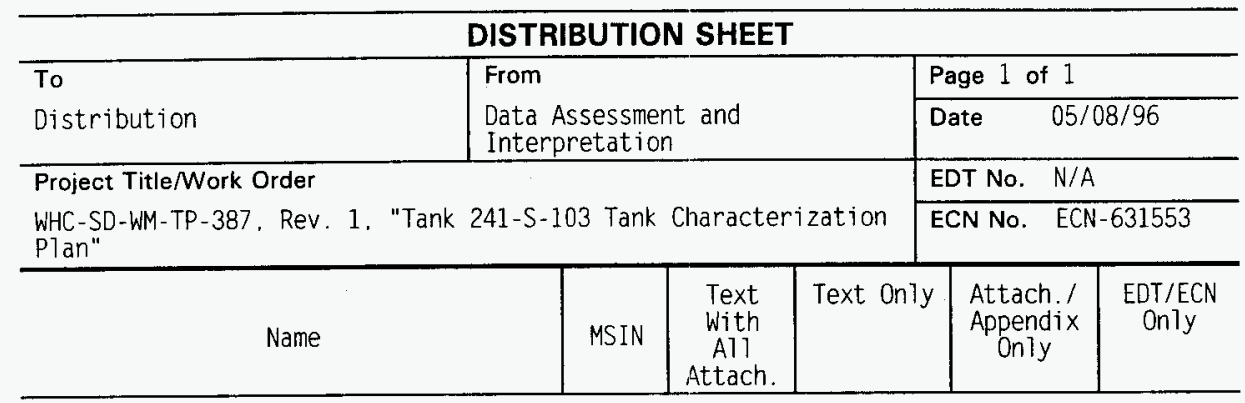

ONSITE

U. S. Department of Energy -

Richland Field office

W. Liou

N. W. Willis

$57-54$

$57-54$

$\hat{x}$

$x$

Westinghouse Hanford Company

G. D. Forehand

C. S. Homi

A. A. Kruger

Central Files

T.C.R.C.

$\begin{array}{ll}\text { S7 }-21 & x \\ R 2-12 & x \\ R 2-12 & x \\ A 3-88 & x \\ R 2-12 & x\end{array}$

\section{OFFSITE}

U. S. Department of Energy - Headquarters

office of Environmental Restoration and Waste Management EM-563

12800 Middlebrook Road

Germantown. MD 20874

J. A. Poppiti 